\title{
Influence of nitrogen and row spacing on Sesame (Sesamum indicum L.) growth and yield attributes
}

\author{
Said Badshah ${ }^{1}$, Shad Khan Khalil ${ }^{1}$, Fazal Jalal ${ }^{2 *}$, Abdul Baseer ${ }^{3}$, \\ Muhammad Suleman ${ }^{1}$, Haris Khan ${ }^{1}$, Sajid Khan ${ }^{1}$ and Sajjad Zaheer ${ }^{1}$ \\ 1. Department of Agronomy The University of Agriculture Peshawar-Pakistan \\ 2. Department of Agriculture Abdul Wali Khan University Mardan-Pakistan \\ 3. Department of Agriculture University of Swabi-Pakistan \\ *Corresponding author's email: jalal_146@yahoo.com
}

Citation

Said Badshah, Shad Khan Khalil, Fazal Jalal, Abdul Baseer, Muhammad Suleman, Haris Khan, Sajid Khan and Sajjad Zaheer. Influence of nitrogen and row spacing on sesame (Sesamum indicum L.) growth and yield attributes. Pure and Applied Biology. Vol. 6, Issue 1, pp116-124. http://dx.doi.org/10.19045/bspab.2017.60004

\begin{tabular}{llll}
\hline \hline Received: 01/10/2016 & Revised: 04/01/2017 & Accepted: 08/01/2017 & Online First: 11/01/2017 \\
\hline
\end{tabular}

\section{Abstract}

The experiment was carried out to examine sesame growth and yield response to nitrogen and row spacing. Factorial experiments were carried out in randomized complete block design with split plot arrangement. Main plots were allotted to row spacing $(30,45$ and $60 \mathrm{~cm})$ and different rates of nitrogen $\left(0,40,80\right.$ and $\left.120 \mathrm{kgha}^{-1}\right)$ were placed in sub plots. Data on growth and yield traits were recorded using standard manner up to harvest maturity. The results indicated that the impact of nitrogen and row spacing on number of branches plant ${ }^{-1}$, number of capsule plant ${ }^{-1}$, number of seeds capsule ${ }^{-1}, 1000$ grains weight, biological yield, seed yield and harvest index were found significant. However their interactive effects were non-significant. Fertilization of nitrogen at the rate of $80 \mathrm{~kg} \mathrm{ha}^{-1}$ significantly resulted in maximum number of branches plant ${ }^{-1}$ (20), number of capsule plant ${ }^{-1}$ (122), number of seeds capsule ${ }^{-1}$ (57), 1000 grains weight (3.6g), seed yield $\left(375 \mathrm{kgha}^{-1}\right)$ and harvest index (16\%), while maximum biological $\left(2967.4 \mathrm{kgha}^{-1}\right)$ was recorded with $120 \mathrm{~kg} \mathrm{~N} \mathrm{ha}^{-1}$. Likewise, in case of row spacing, $45 \mathrm{~cm}$ apart rows resulted in maximum number of branches plant ${ }^{-1}$ (19.4), number of capsule plant ${ }^{-1}$ (120.2), number of seeds capsule $^{-1}(55.5), 1000$ grains weight $(3.5 \mathrm{~g})$, seed yield $\left(351 \mathrm{kgha}^{-1}\right)$ and harvest index $(16 \%)$ while more biological yield $\left(3393 \mathrm{kgha}^{-1}\right)$ were observed in $30 \mathrm{~cm}$ apart rows. Hence nitrogen fertilization at the rate of $80 \mathrm{~kg} \mathrm{ha}^{-1}$ with $45 \mathrm{~cm}$ row spacing is recommended to be superior to get higher sesame yield under climatic conditions of Peshawar valley, Pakistan.

Keywords: Nitrogen; Row spacing; Growth; Yield and yield component

\section{Introduction}

Sesame (Sesamum indicum L.) locally called til, is an annual erect plant of varying varieties and types belong to pedaliacea family, grown from very ancient times for its grains purposes from which oil is extracted and utilized as food and for flavoring purposes. It is of various shapes and nature having erect, branched and tall stem 60 to $120 \mathrm{~cm}$ tall. It bears fruit in the form of pod which is 2.5 to $8.0 \mathrm{~cm}$ in length and of 0.5 to $2.0 \mathrm{~cm}$ diameter. Maturing of pods starts from bottom and runs upward also lower pods start shattering until the 
upper ones mature. Seeds are also of two types cream and black in color ovate and small in size. Mostly preference is given to cream colored seed. Sesame is short day crop and normally flowers in 42 to 45 days [1]. In the world it is reckoned as oldest oilseed and spicy crop. Containing approximately $25 \%$ protein and $50 \%$ oil by composition [2]. Oil extracted from sesame is also considering as the most stable and preferred vegetable oil due to presence of antioxidants (sesamolin, sesamol and sesamum) which give it a distinct nature. Sesame is one of the oldest spice and oilseed crop in the world [3]. Oil extracted from seasame contains $40 \%$ unsaturated fatty acids in the form of linoleic and oleic acid each, and 14\% saturated fatty acids [4]. The carbohydrate composition ranges from 16 to $18 \%$ while that of protein ranges from 17 to $19 \%$ [5]. Due to presence of linolenic acids its industrial value increases and is used in production of perfumes and in medicinal drugs. Its total production is 3.66 million tons throughout the world with Africa singly contributing 0.95 million tons, which is very low and is due to lack of adequate agricultural inputs like fertilizers, improved varieties, and other essential agrochemicals as well as poor agronomic practices [6]. Significant seed losses during threshing are also cited as factors for the low production and productivity of the crop.

It is kharif crop and thorough well in regions where temperature is high throughout the growing season due to its tolerance it grow well in hottest months of the years and is one of the few crops that grow well in July and in early August [7]. Sesame grows well in dry conditions and can tolerate drought as well also respond well to rainfall if waterlogging is avoided. Some cultivars can thorough well in rainfall up to $450 \mathrm{~mm}$. In Pakistan 77.6 ha area is cultivated with sesame with 31.1 tons production annually. In Khyber Pakhtunkhwa the crop is grown on 0.1 ha area with 0.1 tons production annually and average yield is $1000 \mathrm{~kg} \mathrm{ha}^{-1}$ [8]. Its main producers are Myanmar, India, China and Sudan [9].

Pakistan being an agricultural country unfortunately we are facing acute deficiency of edible oil. Because of ever increasing population our demand for edible oils increases day by day and production is decreasing every year. Only 0.680 million tons production is estimated locally which fulfill only $24 \%$ of our requirements while the remaining $76 \%$ edible oil is imported to meet our requirements. Total availability of 1.749 million tons is provisionally estimated from all sources [10]. Our imports can be reduced by bringing more area under cultivation, selection of better variety and though proper management practices which will boost annual production of sesame. In Pakistan reasons of low yield involves improper sowing method (broadcast method), poor seed quality, improper sowing time, and over or less population [11]. By maintaining proper and optimum plant population we can improve our yield therefore row spacing is very important. Without proper row spacing plant population cannot be optimized and hence yield will decrease. In Pakistan all varieties available are well branched and needs more row spacing for better aeration and for maximum harvesting of solar radiation [12]. Nitrogen being an essential nutrient play a vital role in plant nutrition. Nitrogen is an important constituent of organic compounds like proteins, amino acids, nucleic acid, coenzymes, ribosomes, cytochrome, vitamins and most importantly chlorophyll $[13,14]$. Studies have revealed that nitrogen fertilization have positive effects on yield, growth and improving quality of sesame [15]. Another study reported increment in seed index, capsules plant ${ }^{-1}$, seed yield and protein content $\mathrm{ha}^{-1}$ whereas oil content was reported to decrease with nitrogen 
fertilization [16]. Increased in $\mathrm{N}$ doses from 71 to $142 \mathrm{kgha}^{-1}$ yield components were improved and seed yield was increased, however low levels of $\mathrm{N}$ gives low oil content [17], also raising $\mathrm{N}$ application from 71 to $142 \mathrm{kgha}^{-1}$ plant height, no of capsules plant $^{-1}$, size of capsule, grain weight plant ${ }^{-1}$, and grains yield $\mathrm{ha}^{-1}$ were improved. Also, [18] reported increment in number of branches, seed index, capsule plant ${ }^{-1}$, and grain yield plant ${ }^{-1}$ with application of $\mathrm{N}$ up to $120 \mathrm{kgha}^{-1}$.

Keeping in mind the above literature the present study were carried out to optimized $\mathrm{N}$ application and row spacing for remarkable growth and yield of sesame.

\section{Materials and methods}

To investigate the response of sesame growth and yield to varying doses of nitrogen and row spacing an experiment was carried out at the Agronomy Research Farm of The University of Agriculture Peshawar during summer season 2014. Experimental area is situated in Peshawar at $34.01^{\circ} \mathrm{N}$ latitude, $71.35^{\circ} \mathrm{E}$ longitude and at an altitude of $350 \mathrm{~m}$ above sea level. The climate of Peshawar valley is continental type and is situated about $1600 \mathrm{~km}$ north of the Indian Ocean. Major irrigation canal is Warsak canal from the Kabul River. Soil texture is clay loam which has $0.87 \%$ low organic matter and the proportion of other nutrients like phosphorus and potassium are 6.57 and $121 \mathrm{mgkg}^{-1}$ respectively, $\mathrm{pH}$ (8.2) is alkaline and calcareous in nature [19]. The factorial trial was carried out in randomized complete block design with split plot arrangement possessing three replications. Three row spacing $(30,45$ and $60 \mathrm{~cm})$ were assigned to main plots while nitrogen rates $\left(0,40,80\right.$ and $\left.120 \mathrm{kgha}^{-1}\right)$ were placed in the sub-plots. There were 5 rows in each sub plot. Field was irrigated on 21-06-2014 and land preparation was carried out on 27-062014. Sowing was carried out at morning on 28-06-2014. Phosphorus fertilization at the rate of $60 \mathrm{kgha}^{-1}$ was applied. Seed was sown at the rate of $5 \mathrm{kgha}^{-1}$ and all other field practices were performed uniformly during the whole growing season. Emergence was started on 02-07-2014 three days after sowing. First irrigation was given 4 days after emergence and the field was three times irrigated during the whole growing season. Severe attack of bacterial leaf blight was noticed twice, first 17 days and second 40 days after emergence which was treated with lambda cylothrin EC-200.

Factors studied in the experiment were:

\section{Factor A. Row spacing (cm)}

$\mathrm{R} 1=30$
$\mathrm{R} 2=45$
$\mathrm{R} 3=60$

Factor B. Nitrogen rates $\left(\mathrm{kg} \mathrm{ha}^{-1}\right)$

$\mathrm{N} 1=0$

$\mathrm{N} 2=40$

$\mathrm{N} 3=80$

$\mathrm{N} 4=120$

Parameters on which data were recorded

1. Number of branches plant ${ }^{-1}$

2. Number of capsules plant ${ }^{-1}$

3. Number of seeds capsule ${ }^{-1}$

4. Thousand seed weight

5. Seed yield

6. Biological yield

7. Harvest index

Number of branches plant ${ }^{-1}$

Number of branches plant ${ }^{-1}$ were estimated in five plants selected randomly in each subplot and then averaged.

Number of capsules plant ${ }^{-1}$

Number of capsules plant ${ }^{-1}$ were figured out and averaged in five randomly selected plants in each subplot.

Number of seeds capsule ${ }^{-1}$

Data on seeds number capsule ${ }^{-1}$ were noted by estimating seeds in five capsules of randomly selected plants in each subplot and then averaged.

\section{Thousand seeds weight (g)}

Data on thousand seeds weight were noted by figuring out real number of 1000 seeds in 
each subplot at random and then weighed with an electronic balance.

Biological yield ( $\mathrm{kg} \mathrm{ha}^{-1}$ )

Data concerning biological yield was estimated by cutting three central rows in each subplot and were sun dried, weighed with balance and then changed into $\mathrm{kg} \mathrm{ha}^{-1}$ by the given formula:

Biological yield $(\mathrm{kg})$ $\mathrm{x} 10000 \mathrm{~m}^{2}$

Row-row (m) distance $\mathrm{x}$ Row length $(\mathrm{m}) \mathrm{x}$ No. of rows

\section{Seed yield $\left(\mathrm{kg} \mathrm{ha}^{-1}\right)$}

Data on seed yield were recorded by harvesting and shelling of capsules of three central rows in each subplot and then sun dried, weighed and changed into $\mathrm{kg} \mathrm{ha}^{-1}$ by the following formula. Grain yield $(\mathrm{kg})$ $\mathrm{x} 10000 \mathrm{~m}^{2}$

Row-row (m) distance $x$ Row length $(\mathrm{m}) \mathrm{x}$ No. of rows

\section{Harvest index (\%)}

Harvest index was estimated using the formula

Economic yield $\left(\mathrm{kg} \mathrm{ha}^{-1}\right) \times 100$

Biological yield $\left(\mathrm{kg} \mathrm{ha}^{-1}\right)$

\section{Statistical analysis}

Data were analyzed by using analysis of variance technique based on RCBD with split plot arrangement. Means were compared by using least significant difference (LSD) test at probability $\leq 0.05$ upon significant F-test [20].

\section{Results}

\section{Number of branches plant ${ }^{-1}$}

Data concerning number of branches plant ${ }^{-1}$ of sesame are shown in Table 1. Data analysis showed that both nitrogen $(\mathrm{N})$ and row spacing (RS) have significant effects on number of branches plant ${ }^{-1}$ while $\mathrm{N} \times \mathrm{RS}$ interaction was found non-significant. Plots treated with no nitrogen (control plots) resulted in minimum number of branches plant $^{-1}(15.8)$. Number of branches plant ${ }^{-1}$ enhanced with each increment of nitrogen and significantly maximum number of branches plant ${ }^{-1}$ (20.0) were observed with $80 \mathrm{~kg} \mathrm{~N} \mathrm{ha}^{-1}$. Thereafter, further increase in $\mathrm{N}$ did not increase number of branches plant ${ }^{-}$ 1. Likewise, in case of row spacing, maximum number of branches plant ${ }^{-1}(19.4)$ were noticed at $45 \mathrm{~cm}$ apart rows while narrow row spacing $(30 \mathrm{~cm})$ produced minimum number of branches plant ${ }^{-1}(16.5)$. Number of capsules plant ${ }^{-1}$

Data analysis showed that number of capsules plant ${ }^{-1}$ were significantly affected by nitrogen $(\mathrm{N})$ and row spacing (RS) while $\mathrm{N} x$ RS interaction was found nonsignificant (Table 1). Control plots resulted in minimum number of capsules plant ${ }^{-1}$ (107.6). Increase in nitrogen fertilization increased number of capsules plant ${ }^{-1}$ and significantly maximum number of Capsules plant $^{-1}$ (122.0) were observed with $80 \mathrm{~kg} \mathrm{~N}$ $\mathrm{ha}^{-1}$. After that, further enhancement in $\mathrm{N}$ did not elevate capsules plant ${ }^{-1}$. In case of row spacing, $45 \mathrm{~cm}$ apart rows generated maximum number of capsules plant ${ }^{-1}$ (120.2) while narrow row spacing $(30 \mathrm{~cm})$ produced

number of capsules plant ${ }^{-1}$ (111.2).

Number of seeds capsule ${ }^{-1}$

Data analysis showed that nitrogen $(\mathrm{N})$ and row spacing (RS) had significant effects on number of seeds capsule ${ }^{-1}$ while their interaction were found non-significant (Table 1). Nitrogen application at the rate of $80 \mathrm{kgha}^{-1}$ produced maximum number of seeds capsule $^{-1}$ (55.67) while minimum number of seeds capsule ${ }^{-1} \quad$ (48.89) were recorded in control plots. Similarly, narrow row spacing $(30 \mathrm{~cm})$ produced minimum number of seeds capsule ${ }^{-1}$ (49.70) while maximum number of seeds capsule ${ }^{-1}$ (55.25) were observed at $45 \mathrm{~cm}$ apart rows. 
Table 1. Number of branches plant ${ }^{-1}$, number of capsules plant ${ }^{-1}$ and number of seeds capsule $^{-1}$ of sesame as affected by various levels of nitrogen and row spacing

\begin{tabular}{|l|c|c|c|}
\hline & $\begin{array}{l}\text { Number of branches } \\
\text { plant }^{-1}\end{array}$ & $\begin{array}{l}\text { Number of capsules } \\
\text { plant }^{-1}\end{array}$ & $\begin{array}{l}\text { Number of seeds } \\
\text { capsule }^{-1}\end{array}$ \\
\hline Row spacing (cm) & & & \\
\hline $\mathbf{6 0}$ & $18.8 \mathrm{~b}$ & $118.2 \mathrm{~b}$ & $54.43 \mathrm{a}$ \\
\hline $\mathbf{4 5}$ & $19.4 \mathrm{a}$ & $120.2 \mathrm{a}$ & $55.25 \mathrm{a}$ \\
\hline $\mathbf{3 0}$ & $16.5 \mathrm{c}$ & $111.2 \mathrm{c}$ & $49.70 \mathrm{~b}$ \\
\hline LSD $(\mathbf{0 . 0 5})$ & 0.64 & 2.01 & 1.28 \\
\hline Nitrogen $\left(\mathbf{k g ~ h a}^{-\mathbf{1}}\right)$ & & & \\
\hline $\mathbf{0}$ & $15.8 \mathrm{~d}$ & $107.6 \mathrm{c}$ & $48.89 \mathrm{c}$ \\
\hline $\mathbf{4 0}$ & $17.8 \mathrm{c}$ & $116.5 \mathrm{~b}$ & $53.94 \mathrm{~b}$ \\
\hline $\mathbf{8 0}$ & $20.0 \mathrm{a}$ & $122.0 \mathrm{a}$ & $55.67 \mathrm{a}$ \\
\hline $\mathbf{1 2 0}$ & $19.2 \mathrm{~b}$ & $119.8 \mathrm{a}$ & $54.02 \mathrm{~b}$ \\
\hline LSD $(\mathbf{0 . 0 5})$ & 0.61 & 2.88 & 1.53 \\
\hline
\end{tabular}

Thousand seeds weight (g)

Data concerning thousand seeds weight indicated that both nitrogen and row spacing had significantly affected thousand seeds weight while their interactive effects were found nonsignificant (Table 2). From the data it is cleared that highest thousand seeds weight (3.6 g) were observed with the application of $80 \mathrm{~kg} \mathrm{~N} \mathrm{ha}^{-1}$ matched with control plots $(3.3$ g). Likewise, narrow row spacing $(30 \mathrm{~cm})$ resulted in lowest thousand seeds weight $(3.3 \mathrm{~g})$ while highest thousand seeds weight (3.5 g) were observed with $45 \mathrm{~cm}$ apart rows.

Seed yield $\left(\mathrm{kg} \mathrm{ha}^{-1}\right)$

Statistical analysis of data presented in Table 2 cleared that seed yield was significantly affected by nitrogen and row spacing while $\mathrm{N} \times \mathrm{RS}$ interaction was found non-significant. Application of nitrogen at the rate of $80 \mathrm{kgha}^{-1}$ resulted in maximum grain yield (375.1 $\left.\mathrm{kgha}^{-1}\right)$ while minimum grain yield (288.6 $\mathrm{kgha}^{-1}$ ) was noted in control plots. In case of row spacing, highest grain yield (350.9 $\mathrm{kg} \mathrm{ha}^{-1}$ ) was observed at $45 \mathrm{~cm}$ apart rows whereas lowest seed yield (340.7 $\mathrm{kgha}^{-1}$ ) was noticed with $60 \mathrm{~cm}$ row spacing.
Biological yield ( $\left.\mathrm{kg} \mathrm{ha}^{-1}\right)$

Data analysis indicated that nitrogen and row spacing had significantly affected biological yield while the interaction of nitrogen and row spacing was found nonsignificant (Table 2). Highest biological yield (2967.4 $\left.\mathrm{kgha}^{-1}\right)$ was observed with the application of $120 \mathrm{~kg} \mathrm{~N}$ $\mathrm{ha}^{-1}$ whereas lowest biological yield (2472.1 $\mathrm{kgha}^{-1}$ ) was resulted from control plots. Likewise, $30 \mathrm{~cm}$ row spacing produced maximum biological yield (3393.0 $\mathrm{kgha}^{-1}$ ) while minimum biological yield (2262.6 $\mathrm{kg} \mathrm{ha}^{-1}$ ) was observed at $60 \mathrm{~cm}$ row spacing

Harvest index (\%)

Data analysis concerning harvest index showed that both nitrogen $(\mathrm{N})$ and row spacing (RS) had significant effects whereas $\mathrm{N} x \mathrm{RS}$ interaction was found nonsignificant (Table 2). Nitrogen application at the rate of $80 \mathrm{kgha}^{-1}$ resulted in maximum harvest index $(15.9 \%)$ whereas minimum harvest index (14\%) was recorded in control plots. Similarly, minimum harvest index $(14.5 \%)$ was recorded at $30 \mathrm{~cm}$ apart rows while maximum harvest index $(15.9 \%)$ was observed at $45 \mathrm{~cm}$ row spacing. 
Table 2. Thousand seeds weight, seed yield, biological yield and harvest index of sesame as affected by various levels of nitrogen and row spacing

\begin{tabular}{|c|c|c|c|c|}
\hline & $\begin{array}{l}\text { Thousand seeds } \\
\text { weight (g) }\end{array}$ & $\begin{array}{l}\text { Seed yield } \\
\left(\mathrm{kg} \mathrm{ha}^{-1}\right)\end{array}$ & $\begin{array}{l}\text { Biological } \\
\text { yield }\left(\mathrm{kg} \mathrm{ha}^{-1}\right)\end{array}$ & $\begin{array}{c}\text { Harvest index } \\
(\%)\end{array}$ \\
\hline \multicolumn{5}{|c|}{ Row spacing (cm) } \\
\hline 60 & $3.4 \mathrm{~b}$ & $340.7 \mathrm{~b}$ & $2262.6 \mathrm{c}$ & $14.9 \mathrm{~b}$ \\
\hline 45 & $3.5 \mathrm{a}$ & $350.9 \mathrm{a}$ & $2596.2 \mathrm{~b}$ & $15.9 \mathrm{a}$ \\
\hline 30 & $3.3 \mathrm{c}$ & $349.6 \mathrm{a}$ & $3393.0 \mathrm{a}$ & $14.5 \mathrm{c}$ \\
\hline LSD (0.05) & 0.03 & 2.25 & 45.34 & 0.28 \\
\hline \multicolumn{5}{|c|}{ Nitrogen $\left(\mathrm{kg} \mathrm{ha}^{-1}\right)$} \\
\hline 0 & $3.3 \mathrm{c}$ & $288.6 \mathrm{c}$ & $2472.1 \mathrm{~d}$ & $14.0 \mathrm{c}$ \\
\hline 40 & $3.3 \mathrm{c}$ & $351.1 \mathrm{~b}$ & $2715.3 \mathrm{c}$ & $14.7 \mathrm{~b}$ \\
\hline 80 & $3.6 \mathrm{a}$ & $375.1 \mathrm{a}$ & $2847.6 \mathrm{~b}$ & $15.9 \mathrm{a}$ \\
\hline 120 & $3.4 \mathrm{~b}$ & $373.4 \mathrm{a}$ & $2967.4 \mathrm{a}$ & $15.8 \mathrm{a}$ \\
\hline LSD (0.05) & 0.09 & 4.12 & 66.05 & 0.40 \\
\hline
\end{tabular}

Means in rows or column followed by the same letters are not significantly different at $p \leq 0.05$ by using LSD test

\section{Discussion}

From data analysis it is revealed that both nitrogen $(\mathrm{N})$ and row spacing $(\mathrm{RS})$ have significantly affected number of branches plant $^{-1}$ while the interactive effect of $(\mathrm{N} \mathrm{x}$ RS) were non-significant. Control plot gives minimum number of branches plant ${ }^{-1}(15.8)$. With each increment of $\mathrm{N}$ number of branches plant ${ }^{-1}$ increased and maximum branches plant $^{-1}$ (20) were reported with 80 $\mathrm{kg} \mathrm{N} \mathrm{ha}^{-1}$. However further increase in $\mathrm{N}$ has no significant effect on number of branches plant $^{-1}$. Data regarding row spacing, narrow row spacing $(30 \mathrm{~cm})$ gives minimum number of branches plant ${ }^{-1}(16.5)$ while row spacing with $45 \mathrm{~cm}$ recorded maximum (19.4) no of branches plant ${ }^{-1}$. Number of branches plant ${ }^{-1} \quad$ increased with application of nitrogen. Sesame planted at an inter row spacing of $7.5 \mathrm{~cm}$ were shorter, having lower LAI, TDM and number of branches plant ${ }^{-1}$ compared with those planted at wider spacing. Possible reason is that at close spacing number of plants per unit increases compared with wider spacing. Due to which completion for light, space and nutrients increases however at wider spacing competition among plants decreases thereby producing taller plants with high LAI, TDM and number of branches plant ${ }^{-1}$.
Similar results were also reported by [21]. Who investigated maximum number of branches plant ${ }^{-1}$ with application of $120 \mathrm{~kg}$ $\mathrm{Nha}^{-1}$.

Data analysis revealed that both nitrogen $(\mathrm{N})$ and row spacing (RS) had significantly affected number of capsules plant $^{-1}$ while interaction between ( $\mathrm{N} \quad \mathrm{RS})$ was found non-significant. In control plots minimum number of capsules plant ${ }^{-1}$ (107.6) were observed. With each increment of $\mathrm{N}$ capsules plant ${ }^{-1}$ increases and maximum capsules plant ${ }^{-1}$ (122.0) were reported with $80 \mathrm{~kg} \mathrm{~N} \mathrm{ha}^{-1}$. Thereafter, further increment in $\mathrm{N}$ did not enhanced capsules plant ${ }^{-1}$. Minimum capsules plant ${ }^{-1} \quad$ (111.2) were reported in plots with narrow row spacing $(30 \mathrm{~cm})$, while plots having row spacing $45 \mathrm{~cm}$ apart recorded maximum (120.2) number of capsule plant ${ }^{-1}$. Yield components such as number of capsules plant ${ }^{-1}$, capsule yield plant ${ }^{-1}$, seed yield plant ${ }^{-1}$ and seed yield ha ${ }^{-1}$ were all optimized at moderate $\mathrm{N}$ level $\left(80 \mathrm{~kg} \mathrm{~N} \mathrm{ha}^{-1}\right)$ and not the highest $\mathrm{N}$ level $\left(120 \mathrm{~kg} \mathrm{ha}^{-1}\right)$ as in growth characters. Our results are in conformity with that of [22] who investigated that excessive nitrogen only improve plant growth while reduces yield and fruit number. Statistical analysis of the 
data showed that nitrogen and row spacing had significantly affected number of seeds capsule ${ }^{-1}$ while interaction between $(\mathrm{N}$ $\mathrm{x}$ RS) was found non-significant. Nitrogen application at the rate of $80 \mathrm{kgha}^{-1}$ reported maximum number of seeds capsule ${ }^{-1}$ (55.67), followed by $120 \mathrm{~kg} \mathrm{~N} \mathrm{ha}{ }^{-1}$ while control plots yields minimum number of seeds capsule ${ }^{-1}$ (48.89). In case of row spacing, minimum (49.70) numbers of grains capsule- 1 were recorded in plots with narrow row spacing $30 \mathrm{~cm}$ apart. Row spacing with $45 \mathrm{~cm}$ apart gives maximum number of capsules plant ${ }^{-1}$ (55.25). More grains capsule ${ }^{-1}$ were recorded at application of higher doses of nitrogen while lower doses reported minimum number of grains capsule $^{-1}$. This might be due to high nitrogen use efficiency and more interception of sunlight due to more number of leaves and and as a result more photo assimilates go to seeds. These results are in conformity with findings of [23] reported that increase in nitrogen application had increased the number of seeds capsule ${ }^{-1}$.

Date regarding 1000 grains weight was significantly enhanced by application of $\mathrm{N}$. Statistical analysis of the data revealed that 1000 grains weight increased with each increment of nitrogen and highest thousand grains weight $(3.6 \mathrm{~g})$ were recorded with $80 \mathrm{~kg} \mathrm{~N} \mathrm{ha}^{-1}$ compared to control plots $(3.3 \mathrm{~g})$.In case of row spacing the maximum thousand seeds weight $(3.5 \mathrm{~g})$ were reported in $45 \mathrm{~cm}$ rows apart, followed by $60 \mathrm{~cm}$ and $30 \mathrm{~cm}$ respectively. The interactive effect of nitrogen and row spacing on thousand seeds weight was found non-significant. This result is supported with the findings of [23] who reported the highest thousand grain weight $(\mathrm{g})$ at $80 \mathrm{~kg} \mathrm{~N} \mathrm{ha}^{-1}$.

Form analysis of data it was observed that both $\mathrm{N}$ and RS signify seed yield while interaction between ( $\mathrm{N} \times \mathrm{RS}$ ) was found non-significant. Nitrogen application at the rate of $80 \quad \mathrm{~kg} \mathrm{ha}^{-1}$ recorded maximum yield $\quad\left(375.1 \quad \mathrm{~kg} \mathrm{ha}^{-1}\right), \quad$ while minimum seed yield $\left(288.6 \mathrm{~kg} \mathrm{ha}^{-1}\right)$ was reported in control plots. Plots with $45 \mathrm{~cm}$ row spacing recorded maximum seed yield (350.9 $\mathrm{kgha}^{-1}$ ) compared with plots having row having row spacing $60 \mathrm{~cm}$ apart recorded minimum yield (340.7 $\mathrm{kgha}^{-1}$ ). These results are in corroboration with the findings of $[23,24]$ who investigated more grain yield with increased application of nitrogen. [12] also reported that sesame seed yield ha $^{-1}$ increased with increasing plant density up to a maximum means narrow row spacing.

Data regarding biological yield showed that both $\mathrm{N}$ and $\mathrm{RS}$ statistically affected biological yield. Nitrogen application at the rate of $120 \mathrm{kgha}^{-1}$ recorded maximum $\left(2967.4 \mathrm{kgha}^{-1}\right) \quad$ biological yield, while minimum (2472.1 $\mathrm{kgha}^{-1}$ ) biological yield was observed in control plots. Similarly plots having row spacing $30 \mathrm{~cm}$ apart reported highest biological yield (3393.0 $\mathrm{kg} \mathrm{ha}^{-1}$ ), while minimum biological yield $\left(2262.6 \mathrm{kgha}^{-1}\right)$ was recorded in plots with $60 \mathrm{~cm}$ apart rows. However the interaction of nitrogen and row spacing ( $\mathrm{N} \times \mathrm{RS})$ was found non-significant. This increment in biological yield may be attributed to more number of pods plant $^{-1}$, increased plant height and more number of branches plant $^{-1}$ that might enhances total biomass of the plant and resulted in maximum biological yield. These results are in conformity with the findings of $[25,26]$ who reported that increment in nitrogen application improve different yield components which as a result enhanced the biological yield. The reason for maximum biological yield with $30 \mathrm{~cm}$ row spacing might be due to high number of plants $\mathrm{m}^{-2}$.

Analysis of the data revealed that both $\mathrm{N}$ and RS significantly affected harvest index. Maximum harvest index (15.9\%) was reported with $80 \mathrm{~kg} \mathrm{~N} \mathrm{ha}^{-1}$ while minimum 
harvest index (14\%) was observed in control plots. Similarly highest harvest index (15.9\%) was recorded at $45 \mathrm{~cm}$ row spacing whereas minimum harvest index (14.5\%) were recorded at $30 \mathrm{~cm}$ apart rows. However the interaction of nitrogen and row spacing (N x RS) was found non-significant. This result was also supported by [21, 27] who observed that phosphorus and nitrogen application had significantly affected grain yield. As harvest index is correlated with grain yield, therefore increase in grain yield increase harvest index.

\section{Conclusion}

It is concluded from the results that application of nitrogen @ $80 \mathrm{~kg} \mathrm{ha}^{-1}$ with $45 \mathrm{~cm}$ row spacing had significantly improved the yield and yield components of sesame except biological yield which optimized with $120 \mathrm{~kg} \mathrm{~N} \mathrm{ha}^{-1}$ and $30 \mathrm{~cm}$ row spacing, whereas growth characters were also optimized with $80 \mathrm{~kg} \mathrm{~N}^{-1}$ with $45 \mathrm{~cm}$ apart rows. Highest harvest index was recorded with $80 \mathrm{~kg} \mathrm{~N} \mathrm{ha}^{-1}$ with $45 \mathrm{~cm}$ row spacing.

\section{Authors' contributions}

Conceived and designed the experiments: $S$ Khan \& F Jalal, Performed the experiments: $S$ Badshah, $M$ Suleman \& $H$ Khan, Analyzed the data: S Khan \& S Zaheer, Contributed reagents/ materials/ analysis tools: F Jalal, S Badshah \& A Baseer, Wrote the paper: S Badshah, SK Khalil \& F Jalal.

\section{Acknowledgment}

I am indeed thankful to all coauthors specially Prof. Dr. Shad Khan, Department of Agronomy, the University of Agriculture, KPK Peshawar for his moral and technical support in this research study.

\section{Refrences}

1. Nazir MS, Bhatti IH \& Ahmad R (2005). Agronomic traits of Sesame as affected by grain legumes intercropping and planting pattern. Pak $j$ Agri sciences 42: 1-2.
2. Hatam M \& Abbasi GO (1994). "Oilseed Crops" In: Crop production. 1stPrint National Book Foundation, Islamabad: 358-362.

3. Olowe VIO \& Busari LD (2003). Growth and grain yield of two sesame (Sesamum indicum L.) varieties as affected by row spacing in Southern Guinea savanna of Nigeria. Samaru $J$ Agric Res 19: 91-101.

4. Wood R (1999). The New Whole Foods Encyclopedia: A comprehensive resource for healthy eating. Penguin Putnam Inc., New York.

5. Ustimenko-Bakumovsky GV (1983). Plant Growing in the Tropics and subTropic. Mir Pub, Moscow. 273-279.

6. Ashri A (1994). Genetic resources of sesame: present and future perspectives. In:Arora, R.K., Riley, K.W. (Eds.), Sesame biodiversity in Asia: conservation, evaluation and improvement. IPGRI, New Delhi.2539.

7. Rahnama A \& Bakhshandeh A (2006). Determination of optimum row-spacing and plant density for uni-branched sesame in Khuzestan province. J Agric Sci Technol 8: 25-33.

8. MINIFA (2011). Ministry for Food and Agriculture statistic of Pakistan. Govt. of Pakistan, economic wing, Islamabad.

9. FAO (2012). Food and Agricultural Organization of the United Nation: Faostat Database".Available on line. http; fao.org.site,567: default.aspx.

10. GOP (2010). Government of Pakistan, Ministry of Food, Agriculture and Livestock, Finance Division, Economic Advisor Wing, Islamabad Pakistan. 23.

11. Ashri A (1998). Sesame breeding. Plant Breeding Reviews 16: 179-228.

12. Tahir M, Saeed U, Ali A, Hassan I, Naeem M, Ibrahim M, Rehman H \& Javed HMR (2012). Optimizing sowing date and row spacing for newly 
evolved Sesame variety TH-6. Pak J Life Soc Sci 10(1): 1-4.

13. Marschner H (1986). Mineral nutrition of higher plants. Academic Press INC, U.S.A. 674.

14. Noorka IR, Rehman S, Haidry JR, Khaliq I, Tabassam S \& Din M (2009). Effect of water stress on physicochemical properties of wheat (Triticum aestivum L.). Pak J Bot 41(6): 29172924.

15. Basha HA (1994). Response of two sesame cultivars to nitrogen level in newly reclaimed sandy soil. Zagazig $J$ Agric Res 21 (3A): 603-616.

16. Bassiem MM \& Anton NA (1998). Effect of nitrogen and potassium fertilizers and foliar spray with ascorbic acid on sesame plant in sandy soil. Ann Agric Sci Moshtohor 36(1): 95-103.

17. Fayed EHM, Hassan AA \& Hussain SMA (2000). Sesame performance as affected by seeding rate and nitrogen levels under drip irrigation system in newly cultivated sandy soil. I. Yield and yield attributes. Ann Agric Sci Moshtohor 38(1): 65-73.

18. Ashfaq A, Akhtar M, Hussain A, Ehsanullah A \& Musaddique M (2001). Genotypic response of sesame to nitrogen and phosphorus application. Pak J Agric Sci 38(1-2): 12-15.

19. Khan A, Jan MT, Marwat KB \& Arif M (2009). Organic and inorganic nitrogen treatment effect on plant and yield attributes of maize in a different tillage system. Pak J Bot 41: 99-108.

20. Jan MT, Shah P, Hollington PA, Khan MJ \& Sohail Q (2009). Agriculture Research: Design and Analysis, A Monograph. NWFP Agricultural University Peshawar, Pakistan.
21. Haruna IM (2011). Dry matter partitioning and grain yield potential in sesame (Sesamum indicum L.) as influenced by poultry manure, nitrogen and phosphorus at Samaru, Nigeria. Journal of Agricultural Technology 7 (6): 1571-1577.

22. Nahar Z, Mistry KK, Saha AK \& Khaliq QA (2008). Response of nitrogen levels on the yield of sesame (Sesamum indicum L.). SAARC J Agri 6(1): 1-7.

23. Malik MA, Saleem F, Cheema MA \& Ahmad S (2003).Influence of different levels of Nitrogen on productivity of sesame under varying planting pattern. Int J of Agric and Biology 5(4): 490492.

24. Ahmad R, Shahzad SM, Khalid A, Arshad M \& Mahmood MH (2007). Growth and yield response of wheat (Triticum aestivum L.) and maize (Zea mayzs L.) to nitrogen and LTryptophan enriched compost. Pak J Bot 39(2): 541-549.

25. Muhamman MA \& Gungula DT (2008). Growth parameters of sesame (Sesamum indicum L.) as affected by nitrogen and phosphorous levels in Mubi. Nigeria. J Sustainable Dev in Agri \& Env 3(2): 80-86.

26. EI-Nakhlawy \& Shaheen MA (2009). Response of seed yield, yield components and oil content of the sesame cultivar and nitrogen fertilizer rate diversity. Met Env and arid land Agric Sci 20(2): 21-31.

27. Umar UA, Mahmud M, Abubakar IU, Babaji BA \& Idris UD (2012). Effect of nitrogen fertilizer level and intra row spacing on growth and yield of sesame varieties. Int J Agron Plant Prod 3(4): 139-144. 